\title{
Suburban wilderness in the Houston metropolitan landscape
}

\author{
Deanna H. Schmidt ${ }^{1}$ \\ Pasadena, TX, USA
}

\begin{abstract}
This article examines the intersections of community activism and wilderness in the sprawling suburban and industrial landscapes of Houston, Texas, in the United States. The Houston metropolitan region's rapid urban development, laissez-faire land use planning, and world-class petrochemical industries provide a critical context to explore the material and conceptual relations of wilderness. Building upon recent debates regarding the production of nature, the article argues that wilderness is and always has been integrated into our everyday suburban landscapes. The empirical data discussed reveals the practices and processes (re)producing wilderness materially and conceptually within the contemporary relations of urban life. It challenges us to envision wilderness as internal to society and society as internal to wilderness. The results suggest that wilderness, instead of being external and in need of protection, is internal to the human experience and therefore internal to our urban landscapes.
\end{abstract}

Key Words: wilderness, urban development, production of nature, community activism, Houston, TX

\section{Résumé}

Cet article examine les intersections de l'activisme communautaire et en pleine nature dans les paysages suburbains et industriels que l'étalement autour de Houston, Texas, USA. Le développement urbain rapide de ses régions métropolitaines, la planification du laissez-faire, et les industries pétrochimiques de classe mondiale fournissent un contexte critique pour explorer la matière et les relations conceptuelles de l'espace naturel. Se fondant sur les débats récents concernant la production de la nature, l'article soutient que l'espace naturel a toujours été intégré dans nos banlieues. Les données empiriques examinées révèle les pratiques et les processus (re)produisant l'espace naturel matériellement et conceptuellement dans les relations contemporaines de la vie urbaine. Il nous incite à envisager l'espace naturel comme interne à la société, et la société en interne à l'espace naturel. Les résultats suggèrent que l'espace naturel, au lieu d'être externe et dans le besoin de protection, est interne à l'expérience humaine et donc interne à nos paysages urbains.

Mots-clés: l'espace naturel, le développement urbain, la production de la nature, l'activisme communautaire, Houston, TX

\section{Resumen}

Este artículo examina las intersecciones del activismo comunitario y naturaleza en los crecientes paisajes suburbanos e industriales de Houston, Texas, en Estados Unidos. El rápido desarrollo urbano, el planeamiento liberal del uso de suelo y las industrias petroquímicas de nivel internacional en la zona metropolitana de Houston, proveen un importante contexto para analizar las relaciones materiales y conceptuales de la naturaleza. Con base en recientes debates sobre la producción de naturaleza, este artículo discute que la naturaleza es y siempre ha sido integrada en nuestro cotidiano paisaje suburbano. Los datos empíricos discutidos aquí, revelan las prácticas y los procesos que (re)producen la naturaleza material y conceptual dentro de las relaciones contemporáneas de la vida urbana. Esto nos estimula a concebir a la naturaleza como algo interno a la sociedad y a su vez, a la sociedad como interna a la naturaleza. Los resultados sugieren que la naturaleza en lugar de ser externa y en necesidad de protección, es interna a la experiencia humana y por consiguiente, interna a nuestros paisajes urbanos.

Palabras clave: naturaleza, desarrollo urbano, producción de naturaleza: activismo comunitario, Houston, TX

\footnotetext{
1 Dr. Deanna H. Schmidt, Senior Planning Analyst, City of Pasadena, Pasadena, TX 77502, USA. Email:
} deannahschmidt "at" gmail.com. The author wishes to thank two anonymous referees for their insights. 


\section{Introduction}

Nature...is re-established, recreated and reborn as an immanent element of the new urban order. (Keil and Graham 1998)

If nature is an immanent element of our urban landscapes, could this also be said of wilderness? Wilderness does not come to mind when considering Houston's suburban and industrial landscapes. Instead, many would consider Houston to be a sprawling city dominated by the oil and gas industry. The metropolitan region spans approximately 8,000 square miles $\left(20,720 \mathrm{~km}^{2}\right)$ with a population of over 5 million people (City of Houston 2011b). A 1978 U.S. News and World Report article described Houston not as a city, but as "a phenomenon that's shattering tradition as it expands outward and upward with an energy that stuns even its residents" (Close-Up of America 1978). This terra economica, or capitalist landscape, of highway overpasses, parking lots, tract housing, strip malls, and petrochemical manufacturers appears to forestall wilderness (Goldstein 2013). Yet, it is here. This article describes the production of Houston's wilderness.

Scholars have examined the production of nature (Castree 2001; Harvey 1996; Keil and Graham 1998; McCarthy 1998; Smith, N. 1990). Building on this research, this study argues that wilderness is socially (re)produced through specific practices and processes. It reaffirms that nature and society are not separate spheres. Society and nature are unified as a relational and non-dualistic nexus (Smith, N. 1990; Swyngedouw 1996, 1997). Through the process of capitalist production, nature becomes a means of production and a condition of production; thus separating nature and society (Goldstein 2013; Smith, N. 1990). I argue that the segregating of nature and society proves incomplete, even within terra economica. Drawing upon recent research, I argue that capitalist uneven development produces and continues to (re)produce nature and, in fact, wilderness. I specifically use the concept of wilderness because, unlike nature, wilderness evokes uneasy contradictions; wilderness challenges us. "On the one hand it is in hospitable, alien, mysterious, and threatening; on the other, beautiful, friendly, and capable of elevating and delighting the beholder" (Nash 1982: 4). Wilderness eludes human control as it touches the human spirit deeply. The results discussed below suggest that wilderness has existed and continues to exist internal to Houston's terra economica.

The article examines the production of a suburb of Houston's named Clear Lake City, Armand Bayou Nature Center (ABNC), and the surrounding industrial and suburban landscapes (Figures 1 and 2). ABNC is the Houston metropolitan region's largest wildlife refuge and wilderness preserve, and a declared Coastal Preserve by the State of Texas Parks and Wildlife Department. ABNC reveals the ongoing processes and relations that (re)produce wilderness. The processes and relations of (re)production are both material and conceptual (Schmidt 2008). Examining these material and conceptual relations, the research draws from sources that include archival materials, annual reports, planning documents, and interviews with Houston's environmental leaders, volunteers, and public officials. In the following section, I introduce Houston's urban development context. Next, I explore the concepts of the production of nature and wilderness used in the article. Most of the article discusses the (re)production of ABNC wilderness. The (re)production of wilderness demonstrates that wilderness is internal to (capitalist) social relations and capitalist landscapes.

\section{Houston: the "free enterprise" city}

Not only is Houston frequently referred to as a global energy capital, it has also been labeled the free enterprise city (Feagin 1988; Lin 1995). The city is considered a model of laissez-faire entrepreneurialism (Kirby and Lynch 1987; Vojnovic 2003). Since the discovery of Texas oil in 1901, Houston has grown to become the fourth largest U.S. city. With a population of approximately 45,000 in 1900, Houston grew to a metropolitan region with a population of over 6 million by 2010 (City of Houston 2011a; Vojnovic 2007). Much of this growth occurred between 1960 and 1979 when Houston ranked first in population growth (Figure 3). This economic and population growth demanded spatial growth. The urbanized area of Houston grew by $25 \%$ during the 1960s and 94\% during the 1970s (Figure 4). With the latter, Houston's decentralized suburban development ranked first among metropolitan areas in the United States. Reflecting on Houston's lack of land development regulation and pro-development planning policy, one researcher asked, "Are planners [in Houston] collective capitalists?" (Feagin 1990: 249). 


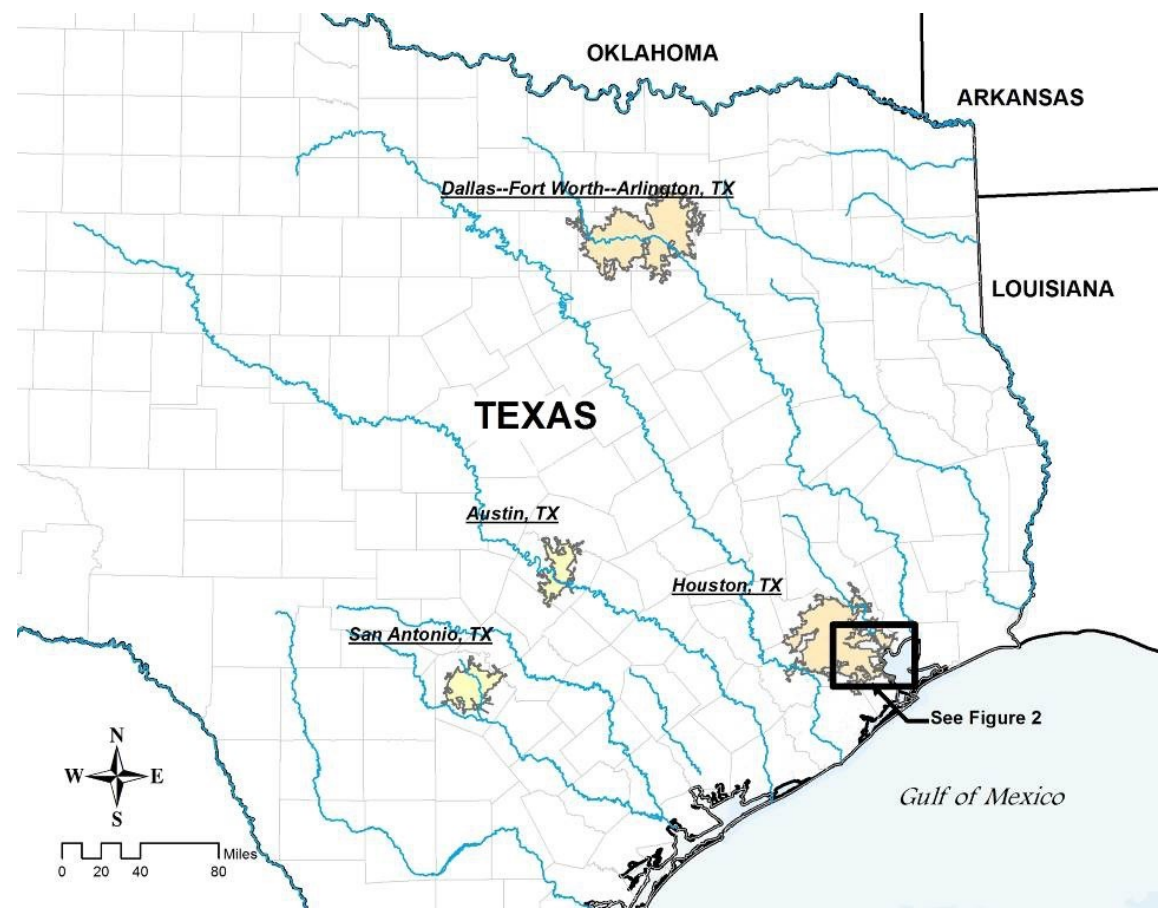

Figure 1: Armand Bayou and Houston, Texas vicinity map.

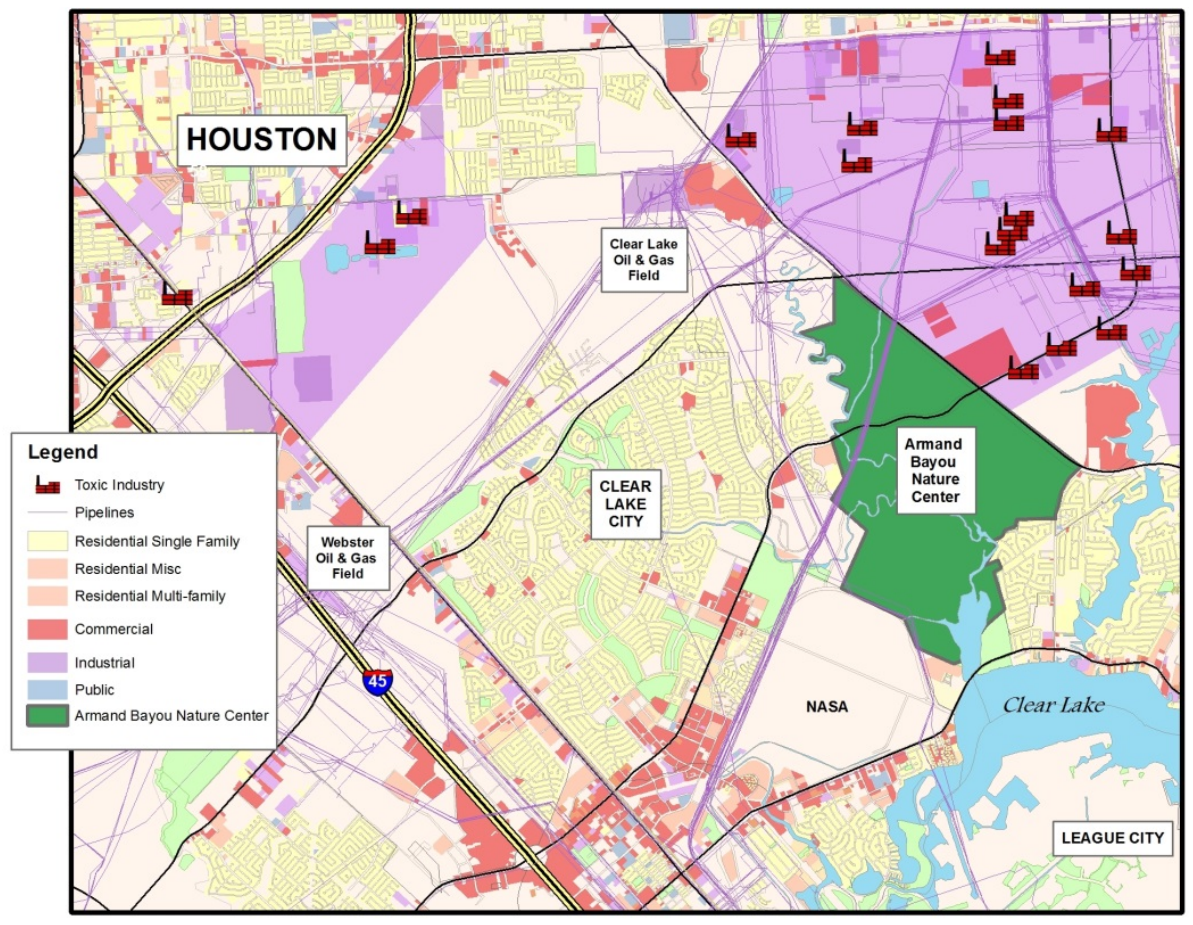

Figure 2: Armand Bayou (in green) location map. Note the surrounding industry, pipelines, and the location of the oil and gas fields. 


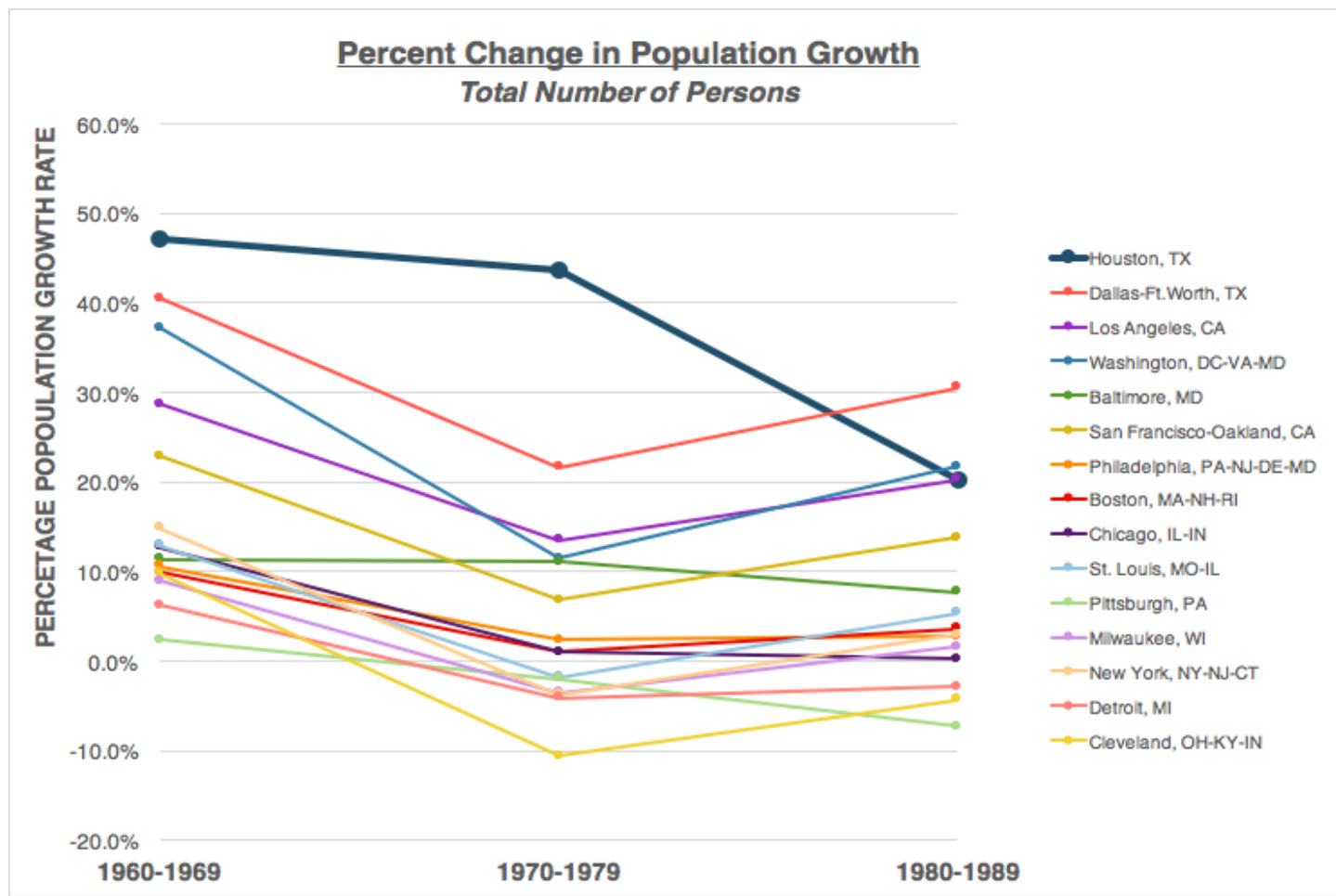

Figure 3: Percent change in population growth 1960-1989, US cities. (U.S. Census 1960, 1970, 1980, 1993).

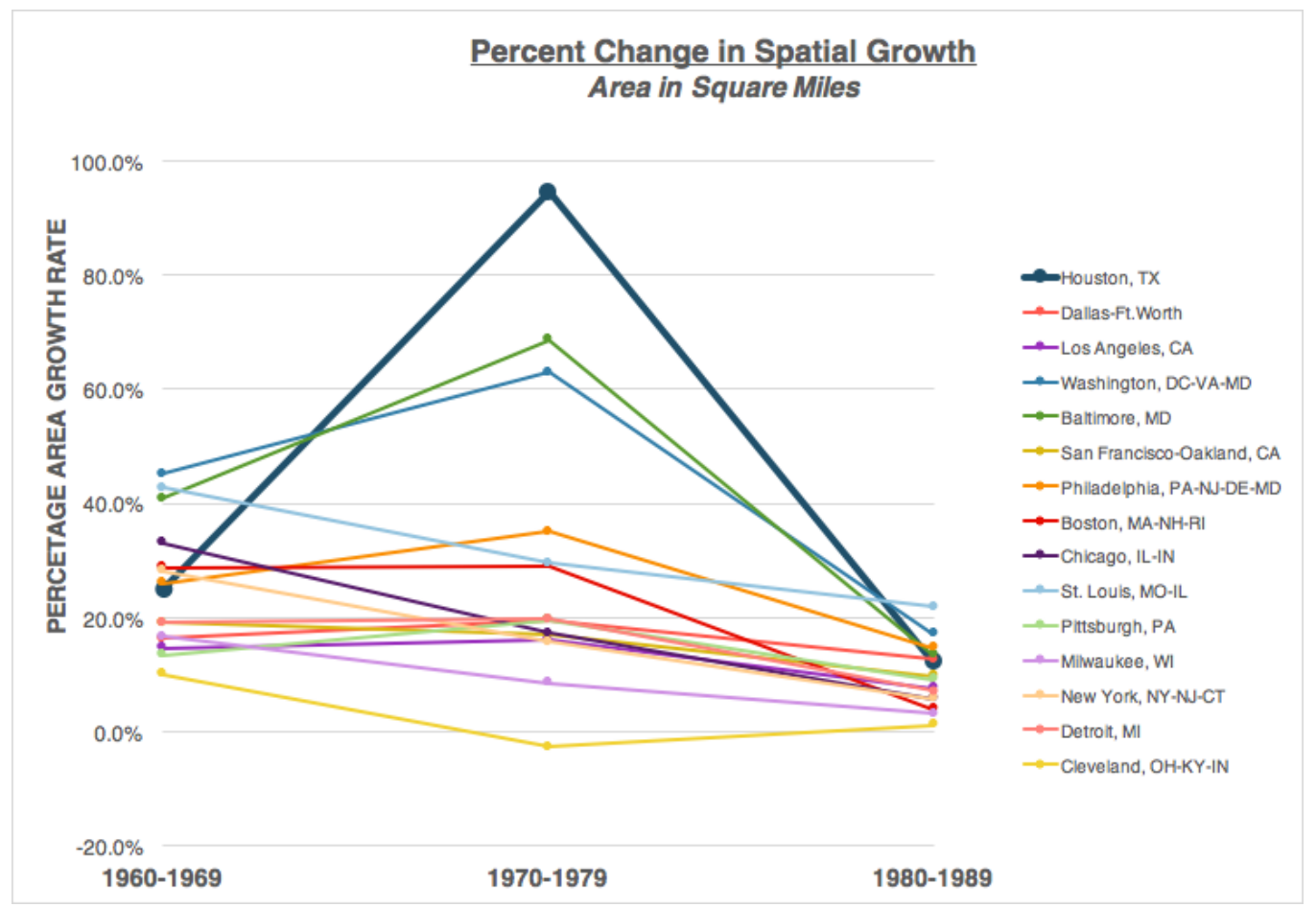

Figure 4: Percent change in spatial growth 1960-1989, US cities. (U.S. Census 1960, 1970, 1980, 1993). 
This tremendous growth had environmental and social costs. For much of the $20^{\text {th }}$ century Houston lacked adequate sewage treatment capacity and suffered from dangerous industrial pollution (Melosi 2007). Toxic pollutants such as benzene and polyvinyl chlorides from oil refineries and chemical manufacturing plants were largely unregulated until the 1970s. Unwanted by-products from the production process could be dumped anywhere, including in local water bodies (Pratt 2007). Unregulated landfills were scattered throughout the metropolitan region (Melosi 2007). During the 1970s, the number of days with severe air pollution ranged from 26 to 112 annually (Fisher 2007). In the 1980s, the region's 44 sewage treatment plants regularly violated State of Texas wastewater standards. The Houston Ship Channel, one of the nation's largest port complexes, was an open sewer for industrial and residential waste (Feagin 1990). Known dangerously polluted sites number over 300 (Kirby and Lynch 1987). The Houston metropolitan region currently has over twenty actively monitored superfund sites $^{2}$ (Texas Commission on Environmental Quality 2014). The Texas Gulf Coast signature, the brown pelican (Pelecanus occidentalis), was all but extinct locally (U.S. Fish and Wildlife Service 2009). Yet, Houston's terra economica integrates some wilderness.

\section{The internal relations of wilderness production}

The approach taken in this article begins with the understanding that nature and society are not separate, interacting entities or systems, but internal relations within a dynamic unity of human and extrahuman processes (Harvey 2009: 231). Therefore, the world is actively being shaped and reshaped by a wide array of intersecting processes, some of which are more human and more capitalist than others. The more human and capitalist processes produce terra economica. In an examination of the history of the English enclosure movement, Goldstein suggests capitalist processes produce terra economica, as potentially commodified materially and conceptually. Materially this involves shifts in land use, land access, land ownership, and in the management of the water, plants, and animals. Conceptually this involves shifts in economic and social value, acceptable future uses, and representations. Terra economica is a means of production as well as a condition of production (Goldstein 2013).

Moore also explores the relations of capitalist natures (Moore 2011, 2014a, c). For Moore, capitalism, and in fact all human activity is simultaneously "producer and product of the web of life" (Moore 2014b: 6). Power, capital, and nature form an organic whole. Capitalism and nature - human, and extra-human collectively produce one another through an ongoing process of becoming. While it is possible to destroy or protect nature, the nature that is destroyed or protected is conceptually-defined by human thought. Moore's work suggests that a fruitful research approach understands nature as historical and immanent to everything humans do including world-wide institutions, civilizations, cities, communities, and our own backyard.

Neil Smith laid the groundwork within geography on the production of nature (Smith, N. 1990, 1996). David Harvey has followed a similar vein with dialectical approach to environmental and social change (Harvey 1996). More recently, Harvey proposes that capital "is a working and evolving ecological system within both nature and capital are constantly being produced and reproduced" (Harvey 2014: 247). Castree has made a similar point: "the production of nature is a continuous process in which nature and capital coconstitute one another in temporarily and geographically varied contingent ways" (Castree 2000: 28, emphasis in original). The production of nature is variegated, contradictory, and multiple across time and space (Harvey 1996). Therefore, it is necessary to historically and geographically situate the production of nature, as this study of wilderness does (Ekers and Loftus 2013).

I argue that wilderness, like nature is produced. A cursory engagement with Marx's philosophy of internal relations is important. It is clear that entities and ideas are related or connected. Ollman (2003) explains how Marx moves beyond the connections between two separate entities and how they influence one another "to cover what is related, so that either term may be taken to express both in their peculiar

\footnotetext{
2 The United States Environmental Protection Agency's Comprehensive Environmental Response, Compensation, and Liability Act of 1980 (CERCLA) authorizes federal funding for the cleanup of sites with hazardous substances and pollutants. CERCLA is also known as the Superfund program. Dangerously contaminated sites identified under the program are identified as superfund sites.
} 
connection." For example, no one will deny that wilderness is interrelated to society. To conceive of wilderness and society as internal relations, as Marx, is to "interiorize this interdependence" (Ollman 2003: 36). Marx argues "That man's physical and spiritual life is linked to nature means simply that nature is linked to itself, for man is part of nature" (Marx 1923: xxiv). When Marx argues that man "is nature", he refers to internal relations; nature is relationally contained in man and man is relationally contained in nature (Ollman 2003: 37). For example, a wilderness such as Yellowstone National Park expresses and relationally contains the social practices and institutions of American society as they have evolved leading up to the creation of the national park system, the university that educated the skilled park ranger performing her job each day, the multinational oil company that manufactured the gasoline powering the automobile used by a Texas family to visit, and the Mexican flowers that nourished a hummingbird on its migratory journey. I propose in this article to draw our attention to the myriad of internal relations embodied materially and conceptually in wilderness/society. In this sense, I leave behind wilderness as an entity interacting with society for an approach that begins with wilderness as an ingredient of society, and society as an ingredient of wilderness.

Roderick Nash begins the Preface of his book, Wilderness and the American mind, with these comments: "Wilderness was the basic ingredient of American civilization. From the raw materials of the physical wilderness Americans built a civilization; with the idea or symbol of wilderness they sought to give that civilization identity and meaning" (Nash 1982: xv). If wilderness is a basic ingredient of American civilization, it has been component of American culture and landscape threaded through with uneasy and often uncontrollable contradictions. The term 'wild' conveys the idea of being lost, unruly, disordered, or confused" (Nash 1982: 1). Unlike the concept of nature, "Americans have found it difficult to be indifferent to...wilderness;" at times fearing it as a hideous and dangerous wasteland to be conquered (Nash 1982: 63), and, at other times, obeying its sublime call for communion and salvation because "wilderness is a necessity" (Muir 1901: 1). Wilderness, unlike nature, demands engagement with a power greater than one's self. Thoreau's prophetic words: "in Wildness is the preservation of the World" was followed by this sentence: "From the forest and wilderness come the tonics and barks which brace mankind" (Thoreau 1914: 46). If Thoreau's wilderness could offer salvation, it came at a price. For example, Thoreau found the Maine wilderness, unlike his beloved Walden Pond, to be "even more grim and wild than you had anticipated, a damp and intricate wilderness in the spring everywhere wet and miry. The aspect of the country indeed is universally stern and savage" (Thoreau 2009: 72). Wilderness can be savage, uncontrollable, and violent (Williams 2014). Yet, Thoreau regarded wilderness as necessary, arguing that "not only for strength, but for beauty, the poet must, from time to time, travel the logger's path and the Indian's trail, to drink at some new and more bracing foundation of the Muses, far in the recesses of the wilderness" (Thoreau 2009: 144).

Aldo Leopold also understood the contradictions and even paradox of wilderness, writing, "Thus does history, whether of marsh or market place, end in paradox. The ultimate value in these marshes is wildness, and the crane is wildness incarnate. But all conservation of wildness is self-defeating, for to cherish we must see and fondle, and when enough have seen and fondled, there is now wilderness left to cherish" (Leopold 1968 (1949): 101). The paradox of wilderness is that its value to humans, and therefore its need for protection, rests in the fact that humans have previously limited their intervention upon its integrity. However, once valued as wilderness, humans undermine its wildness through human intervention to experience, manage, and protect it (Ziser 2011).

Embodying the paradox of wilderness, the Wilderness Act of 1964 established "a National Wilderness Preservation System for the permanent good of the whole people, and for other purposes." The Act defines wilderness "in contrast with those areas where man and his own works dominate the landscape, [wilderness] is hereby recognized as an area where the earth and its community of life are untrammeled by man, where man himself is a visitor who does not remain." Despite recognizing landscapes untouched by man, the Act explicitly provides for wilderness management for the "public purposes of recreational, scenic, scientific, educational, conservation, and historical use." Each agency administering wilderness "shall be responsible for preserving the wilderness character." (United States 88th Congress 1964). In 1968, U.S. Forest Service geographers and social scientists created a framework for preserving the wilderness character which was published in the 1978 Wilderness management handbook. "Just as Forest Service timberlands produced 
lumber for civilization, what wilderness produced was a quality 'wilderness experience' for the visitor" (Smith, J.F. 2014: 36). The Handbook elaborates the production of nature for humans, by humans.

A growing and important body of research examines the complexity of attempting to manage what is defined as wild. Cronon argues that wilderness is not "a pristine sanctuary" (Cronon 1995: 69). Wilderness need not be judged upon ecological purity but instead measured by 'wildness' or reduced human control (Sutter and Cronon 2009). Humans, or the very least, traces of their former settlements continue to exist in the wilderness areas established by the Wilderness Act. Cultural histories of the Apostle Islands National Lakeshore and the Shenandoah National Parks "recycled" wilderness attest to the fascinating interrelations between wilderness and society (Feldman 2013; Reich 2001). Language, advertising, and the media helps to shape the material and conceptual spaces of wilderness (Bryan 2011; DeLuca and Demo 2001). The 'call of the wild' entices to buy vacation homes, motorcycles, and dog food. Marsh (2010) argues that how humans define spatial boundaries is a contentious process that defines wilderness.

Urban wilderness research has also been a fruitful source of insights regarding the interactions of wilderness and society (Hester, Blazej, and Moore 1999; Hofmeister 2009; Langner and Endlicher 2007; Rink 2009). Jorgensen (2008) argues that urban wilderness is generally uncontrolled, unplanned, and unconstructed by conscious human efforts. Extra-human processes predominate in urban wilderness and may generate cultural and biological conflicts with society (Hester, Blazej, and Moore 1999). Urban wilderness may include ruins of homes and factories; it need not be green. Such areas are defined by limited human interrelations at least in the current time and space, resulting in "unorganized voids of ecological succession within the urban fabric" (Desimini 2014: 23; Langner and Endlicher 2007). Urban wilderness preservation, Rink suggests, is a feasible approach for cities undergoing economic restructuring, and in effect, shrinking in population and economic activity (Rink 2009). However, urban wilderness does not automatically follow vacancy, abandonment, and demolition. Instead, urban shrinkage allows us to contemplate a 'resurgence' of nature (Haase 2008: 6). Human agency may be required to transform wastelands into urban wilderness to protect and manage wildlife (Kithiia and Lyth 2011). This transformation may require not only physical changes but conceptual changes if "urban wilderness is able to give the shrinking city new aesthetic and ecological qualities and to turn back or stop the devaluation process" (Rink 2009: 289-290). As such, urban wilderness holds the potential for (re)producing wilderness/social interrelationships.

To summarize, previous research establishes the production of nature. This can be extended to the production of wilderness. Previous research also establishes the dynamic and complex interactions between wilderness and society. What I propose is a shift in vantage point - from wilderness and society as interacting to wilderness as internal to society and society as internal to wilderness. Nature, wilderness, and society are produced though human and extra-human practices and process. Wilderness differs from nature in that wilderness eludes our explicit human control; it is wild; it is uncomfortable; it challenges us. Mary Shelley's Frankenstein reminds us that we can produce but not necessarily control our creations (1999). Wilderness demands not only recognition, but response, to the limits of human knowledge, technology, and abilities. In wilderness, we confront our humanity.

As suggested in the opening quote, I argue that wilderness is re-established, recreated and reborn as an immanent element of the urban order. The concept of wilderness captures the uneasy and often uncontrollable contradictions of the suburban life with the petrochemical industry; the fear of the loss of nature and civilization; and the paradox of cherishing and then attempting to preserve wilderness through human intervention. Even more importantly, the people who struggled to create ABNC specifically engaged the concept of wilderness in their efforts. They used 'wilderness' in correspondence and promotional materials. It seems that, like Muir, they obeyed the sublime call of wilderness and like Thoreau they sought preservation of the World in wildness. The term immanent, as defined by the Oxford English Dictionary, means "indwelling, inherent, actually present or abiding in remaining within" (Oxford English Dictionary 2011). Therefore, wilderness is inherent and constitutive of Houston's terra economica. 


\section{The immanent geographies of Armand Bayou Nature Center}

Harvey, following his reading of Marx, argues that the future already exists in the present world around us (2014). This point certainly applies regarding Armand Bayou Nature Center. Its future wilderness remained immanent and hidden long before it was (re)produced with intensive suburban and industrial development. In 1970, Armand Bayou was unknown to most Houstonians. For most of the 20th century, residents in the immediate vicinity referred to this slow-moving waterway as Middle Bayou. Its humble, slow-moving waters were overshadowed in popularity and economic value by Clear Lake to the south and Galveston Bay to the east (Figure 5). Tidal salt marshes, tall grass wildflower lowlands, and riparian oak woodlands were its coastal companions. Native and migratory wildlife included hawks, bald eagles, herons, pelicans, snakes, alligators, and bison. However, like other local bayous in the Houston metropolitan region, human development has permanently reshaped the bayou's environs. The extraction of oil and gas for energy production and the extraction of water for urban and industrial development caused widespread land subsidence. Unexpectedly and uncontrollably, Middle Bayou's banks and surrounding lowlands sank approximately three meters relative to sea level. This permanently flooded approximately 250 acres (101 ha) of lowland forests and wetlands since 1956 (McFarlane 1991; Zilkoski et al. 2001). Figure 6 compares aerial photographs of Armand Bayou in 1953 (then known as Middle Bayou) and 2002. The 2002 photograph depicts a much wider and shallower expanse of water.

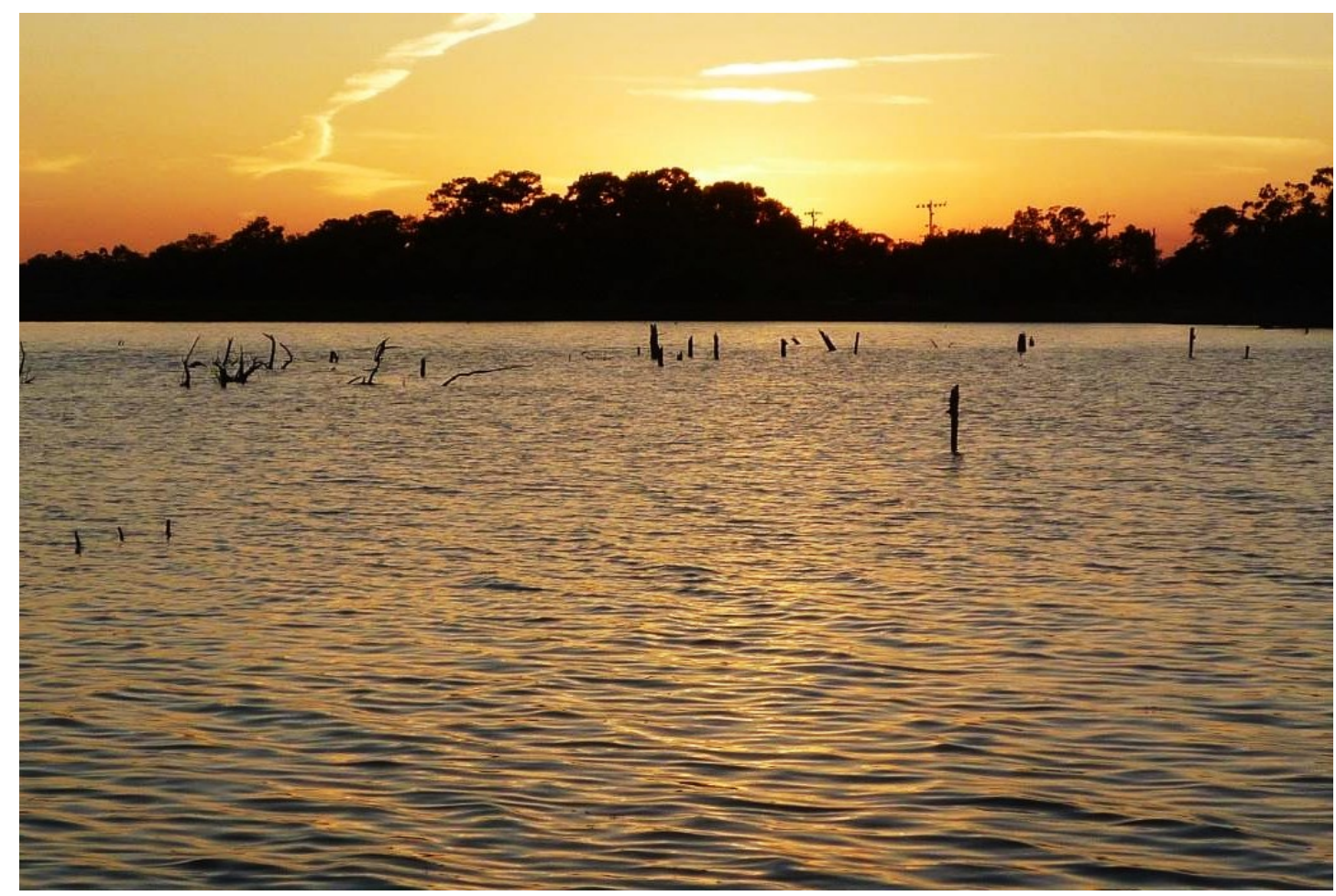

Figure 5: Armand Bayou, 2011. Note the submerged fence line which is the result of subsidence. (Photograph by author) 

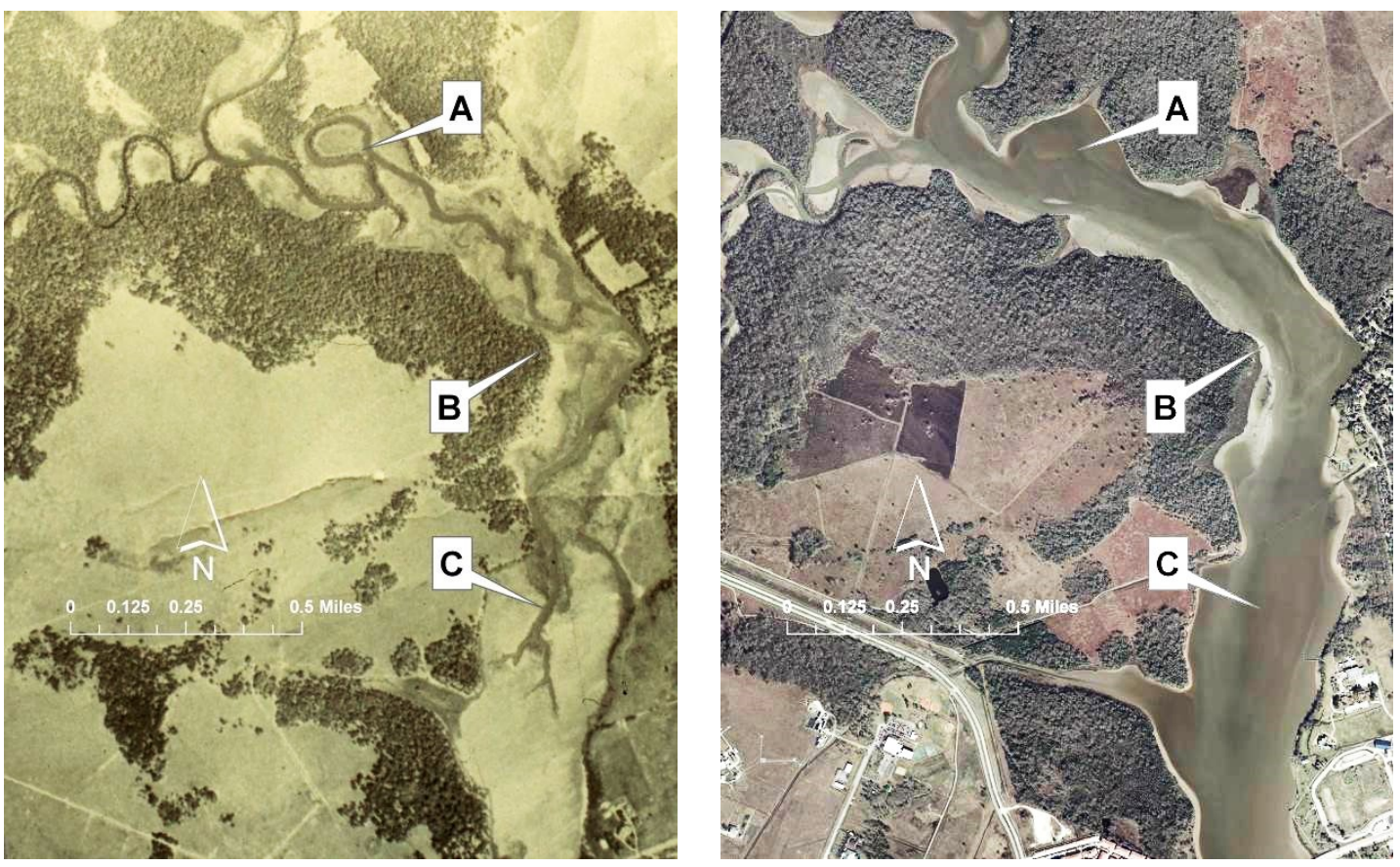

Figure 6: Aerial Photographs of Armand Bayou, 1953 (Left) and 2002 (Right). Subsidence of the land surface increased the area underwater. Both aerial photographs are at normal water levels.

James Herzberg, Middle Bayou's chronicler, writes, "The bayou is a chronicle of human history. Nomadic tribes inhabited the vicinity for thousands of years, moving from campsite to campsite, subsisting off game, fish, nuts, and berries, even yaupon leaves, from which they could brew a strong tea. Early pioneer communities, such as the 'Old French Settlement' of Cajun families, raised sugar cane, cut wood for sale, and grew produce in the decades that they inhabited the vicinity" (1988: 106). The transformation from Middle Bayou's domesticity to Armand Bayou's wilderness is in part a legacy of the oil man and multimillionaire James M. West. In the 1920, Jim West amassed over 12,000 hectares southeast of Houston on the northern shore of Clear Lake, an area that included Armand Bayou (see Figure 2). A legendary figure in the oil industry of Texas, West built a grand mansion on the shores of Clear Lake and managed a productive cattle ranch (Olien 2002; Thomas 1994). Until the local county government built Bay Area Boulevard in 1967, Middle Bayou was only accessible by boat from Clear Lake (Herzberg 1988).

The 1901 discovery of Texas oil dramatically reshaped the Texas economy and politics, and Houston. Several major oil fields were discovered near Houston including the Humble (1905), Goose Creek (1908), Pierce Junction (1921), Tomball (1933), and Webster (1936). The Webster Oil and Gas Field located just six kilometers from Middle Bayou, proved to be one of the most productive. In fact, it continues to be the most productive oil field in the Houston metropolitan region today. The Humble Oil and Refining Company, Exxon Mobil's forerunner, discovered and developed the Webster field. Around 1936, Humble also sought to lease and develop the adjacent Clear Lake oil and gas fields. However, the Clear Lake field was located beneath the grasslands of the Jim West Ranch. Jim West adamantly refused Humble's lease offers for several years, arguing that cattle ranching and drilling for oil were incompatible (Del E. Webb Corporation 1962). In 1938, West agreed to allow Humble to drill on the property upon the condition that Humble purchase the entire ranch and mineral rights, for US\$8.5 million (U.\$140 million in 2015) and US\$30-40 million (US\$500-650 million in 2015) in royalties (Bacon 1995). Only a portion of the ranch, approximately 500 hectares, proved profitable for oil resources development (Thomas 1994). The purchase of the ranch placed 
the Humble Company and its successor, Exxon Mobil, in the business of real estate development for the next twenty years.

By the early 1960s, several factors spurred Humble's entry into real estate development on the West Ranch. First, oil production on the ranch was declining. Second, post-World War II suburban development was rapidly expanding outward from Houston. This outward growth was particularly strong to the southeast of downtown Houston because of the area's proximity to Galveston Bay and Galveston's seaside amenities. The former West Ranch was accessible by the Gulf Freeway, Texas's first freeway completed in 1952. (Highway 45 depicted in Figure 2) Several of Houston's leading real estate developers including George R. Brown of Brown and Root, expressed interest in investment in the area (Bacon 1995; Herzberg 1988).

Discerning the profitability of a major piece of land under single ownership for urban and industrial development, Humble, through a newly created subsidiary, the Friendswood Development Company (FDC), began plans to develop the West Ranch as Clear Lake City. With builder Del Webb Corporation, FDC proposed a master-planned residential community of over 6,000 hectares. FDC also planned the region's second largest industrial complex and international port, second only to the Port of Houston. The plans for Clear Lake City received a crucial boost upon the announcement in 1961 that the National Aeronautics and Space Administration (NASA) would locate the new manned space center in Houston. The manned space center, now known as Johnson Space Center, is located adjacent to Clear Lake City, Armand Bayou Nature Center, and Clear Lake (Figure 2). The announcement "precipitated a titanic construction boom" in the region and expanded FDC's plans to accommodate 180,000 new residents, commercial, and shopping development (Del E. Webb Corporation 1962; Herzberg 1988: 107). The 1962 Clear Lake City Master Plan proposed upper-income single-family lots along Middle Bayou but delayed development along the lower reaches of the bayou. The lower reaches of Middle Bayou, then known as Mud Lake, was deemed unsuitable for residential development due to sewage effluent, shallowness precluded boating, and significant shoreline fluctuation with the tides (Del E. Webb Corporation 1962). The process of (re)producing wilderness required several key relationships to come together on the banks of Middle Bayou and Mud Lake. The following section describes each additional relation in detail.

\section{The (re)production of wilderness at Armand Bayou}

The ABNC's wilderness coalesced through four intertwining relations. First, local activists, including philanthropist Terry (Terese) Hershey (1923-2017), environmentalist Hana Ginzbarg (1925-2013), and religious leader Frank Kokesh, spearheaded the research, promotion, and lobbying for wilderness. As discussed above, Middle Bayou was relatively unknown and certainly not generally deemed to be wilderness. Yet, these local activists, supported by sympathetic reporting in the local press, promoted the 'wildness' of the bayou. Second, subsidence, as noted above, increased the threat of flooding and limited building at the lowest elevations. This greatly limited FDC's profitable options for an area much larger than originally delineated in the 1962 master plans. Third, federal initiatives and funding allocations facilitated the public purchase of land that enabled the (re)creation of wilderness and also its protection. Key federal initiatives supported public access to urban nature and limiting urban development in flood vulnerable areas. Finally, for a short time and uncharacteristically for Texas, local county government financed a county parks department. A one-time bond issue, before the county's elected leadership eliminated the department, allowed the publicly-financed purchase of land most vulnerable to flooding along Middle Bayou. The county purchased the land from FDC and leased it back to ABNC on a 100-year lease. Without the county's actions, ABNC would be greatly reduced in land area and ecological viability. These four intertwining relations, each with internal human and extra-human relations, (re)produced ABNC wilderness.

Local activism and publicity

Finally, I want to say the most important thing that we did was publicity, publicity, publicity, and we germinated a lot of it. (Ginzbarg 2005) 
Hana Ginzbarg's comment explains the importance of community activism and publicity in the (re)production of ABNC wilderness. The spark that ignited this activism was the tragic murder of Armand Yramategui (1923-1970) in January 1970 during a random robbery. Before 1970, Yramategui led efforts to preserve Gulf Coast beaches, rare prairies, and remnants of east Texas pine woods (Anonymous 2001; Herzberg 1995). He deeply appreciated Middle Bayou's "...unspoiled vicinity and felt a natural spot so near to the city and the Manned Spacecraft Center, where so much growth was occurring, should remain untouched" (Herzberg 1988: 114). Yramategui's life work inspired his friends to rename Middle Bayou in his memory. Before the local government administrative body, Frank Kokesh described Middle Bayou as "the best remaining piece of untouched wild-life" in the area and petitioned the local officials to rename the bayou as Armand Bayou (Anonymous 1970). The county approved and thus formally established Armand Bayou. Further promotion established Armand Bayou conceptually as 'wilderness.'

One of the earliest promotional pieces in support of this was published by the Houston Audubon Society:

[O]ne of the few remaining coastal bayous and one in which almost miraculously is in a near complete natural state....Nearly, all the bayous were altered or obliterated - converted into navigation channels for a man's commerce and recreation; irrigation ditches for his agriculture or drainage ditches to aid in making new lands habitable; and many more were cleared to make way for the real estate subdivisions. Yet, through it all and with wondrously little change what we now know as Armand Bayou was spared... (Houston Audubon Society 1970)

This statement characterizes Armand Bayou as qualitatively different. Specifically, the author argues that it was less influenced by human activity than other bayous. However, as noted above, Armand Bayou had been influenced by centuries of human activity and most recently by cattle ranching, oil drilling, and subsidence. Yet in an important sense, it was qualitatively different from similar bayous in the Houston region. Unlike others, it had never been straightened, cleared of vegetation, or lined with concrete. The Houston Audubon Society and Armand Bayou activists recognized this. They formed the Preservation of Armand Bayou Committee (PABC) and began their fight to create the Armand Bayou Nature Center to permanently protect wilderness.

The PABC developed a multimedia campaign as an initial effort in that fight. One important presentation, the 'Hoped-For-Park on Armand Bayou', explained the need for wilderness preservation. A portion of the script reads:

Almost within the shadow of man's labor into tomorrow lies a quiet corner of yesterday. Nearly adjacent to the Manned Spacecraft Center in Harris County is one of the few remaining coastal bayous and one which almost miraculously is in a near complete natural state....Armand Bayou was spared, giving us a rare insight into the ongoing ecology of this coastal marsh...But whether our children will be able to experience Armand Bayou is a matter of question - a matter of deep concern. (Houston Audubon Society 1970)

The Hoped-For-Park presented two themes for the activists' publicity. First, Armand Bayou was a largely untouched natural area, worthy of protection as the last remaining wilderness in the region. Second, its wilderness was crucially needed to provide benefits to people, both enjoyment and education. Similar to Reich's (2001) findings, society creates wilderness, uses wilderness, and positions itself within wilderness.

The activist, Hana Ginzbarg, described Armand Bayou in a letter: "The bayou is so beautiful because it is untouched. One gets a feeling of being miles from civilization when on a boat or when walking along the shore of the bayou" (Ginzbarg 1971c). In another letter she wrote: "As you may know, Armand Bayou is an area of great scenic beauty and ecological significance. It's a remnant of a once widespread coastal marsh...It's a wildlife, wilderness area" (Ginzbarg 1971a). One of her press releases noted: "Preservation of 
the wilderness and unspoiled beauty of the area for the enjoyment and enlightenment of people is the chief aim" (Ginzbarg 1971d).

Local newspapers were also supportive of the wilderness designation and its preservation. The Houston Chronicle wrote: "Middle Bayou, between Clear Lake City and the Bayport Industrial District, is one of Harris County's last untouched wilderness areas....It is the unseen fauna which we must worry about if this area goes under development and the whole bayou is dredged as so many others have been" (Gillaspy 1970). The Houston Post published a series of articles that attested to the importance of Armand Bayou's wilderness. One article described Armand Bayou as:

...one of the last remnants of Harris County where nature has not yet been routed by the bulldozer. Jumping fish break its surface like silver spears...trees bearded with Spanish moss guard its banks...deer slip up through the underbrush to bring at dusk...great blue herons drift across its marshes like half-seen phantoms. It could be a thousand miles from nowhere. (Scarlett 1971)

Another article described the bayou as "a living museum of an ecological past which has now been almost completely destroyed along the Upper Texas Gulf Coast" (Scarlett 1972). A 1973 article supported wilderness preservation based upon the expertise of a local ecologist: "Most important in this growing metropolitan area, it's [Armand Bayou] a beautifully functioning natural ecosystem, with water, air and earth working together to provide vital free benefits to this region" (Scarlett 1973). Through active newspaper publication, letter writing, and promotion, Middle Bayou and Mud Lake were becoming Armand Bayou. Unintended human impacts of urban development - subsidence and flooding - proved to be a crucial second set of internal relations needed for ABNC wilderness.

\section{Flooding and subsidence}

In the 1960s and 1970s, Armand Bayou like all of southeast Houston was subsiding with "shoreline fence posts sinking and docks more frequently covered with water...Palm trees which had grown along the bayou banks...were now in two feet (0.6 meters) of water" (Herzberg 1988: 120). (Figures 3 and 4) Between 1964 and 1973, the Armand Bayou area experienced subsidence of approximately 1.5 meters (Gabrysch and Bonnet 1975; Jacob 2006). Subsidence was the unintended and uncontrolled response to groundwater and oil extraction. With each major tropical storm, flooding problems worsened and areas of wetland and lowlands were lost forever (Houston Galveston Subsidence District 2011). Pointing to the threat of flooding, in a 1972 letter to a local TV station, Hana Ginzbarg explained how Armand Bayou was much more suited to wilderness than residential subdivisions, "I would like to explain why the land is not well suited for residential development. It is low and subject to floods by hurricane tides. Furthermore, it is sinking rapidly...." (Ginzbarg 1972).

Simultaneously, United States federal officials through the Federal Insurance Administration (FIA) began implementing the National Flood Insurance Program. Established in 1968, the program serves as insurer for properties in high-risk flood zones. Initially, local governments refused to join the program because builders and land development companies opposed any restrictions on urban development. FDC broke rank with other Houston developers when local elected leaders voiced concerns about flooding. Understanding the risks of coastal development, FDC supported efforts to secure accurate flood hazards maps in the proposed development area and to prevent construction in areas at greatest risk to flooding. However, the accurate maps, dated 1971, revealed a much larger area than expected within the 100 year flood plain and thus at risk to significant flooding. Approximately 300 hectares were removed from potential development under the federal guidelines for flood insurance. With few profitable prospects for the floodprone land along Armand Bayou, FDC agreed to sell for a sum they considered fair market value. However, Armand Bayou wilderness activists lacked resources to purchase the land from FDC. While subsidence and flooding issues were important, ABNC wilderness required additional federal initiatives and funding allocations. 


\section{Federal initiatives and funding allocations}

The U.S. Department of Housing and Urban Development (HUD) oversaw a program supporting urban open spaces and parks, known as the Legacy of Parks program. The program, initiated by President Richard Nixon in 1971, significantly increased HUD funding for parks and open space in urban areas (Nixon 1971). A very determined PABC lobbied regional HUD officials to support Armand Bayou (Anonymous 1971; Ginzbarg 1971a, b). In early 1972, HUD initially designated US\$1.5 million (US\$8.5 million in 2015) in federal funds for ABNC land acquisition. However, due to appropriation cuts, HUD reduced the allocation to US\$1 million (US\$5.8 million in 2015). With federal funds designated, PABC sought the US\$1 million required local match from the City of Houston.

After the City of Houston refused to appropriate the matching funds, the City of Pasadena, TX, took the initiative and issued certificates of obligation for US\$1 million in 1972. Pasadena shared a border with the City of Houston at Armand Bayou. However, this was a high level of debt for a small, blue-collar Texas community. Herzberg (1988) argues that there are several reasons behind Pasadena's unusual action. The contemporary Pasadena mayor was barred from seeking reelection due to term limits. He could afford spending the political capital needed to win support for protecting Armand Bayou. In addition, growing public awareness and concern regarding flooding, created support for limiting urban development in areas that could exacerbate flooding upstream.

With federally and locally allocated funds, Pasadena purchased nearly 400 hectares of the most floodprone land from FDC. Without Pasadena's unusual action, the ABNC wilderness activists would have likely lost federal funding. Herzberg (1988) stresses that "[Pasadena] city government had never really endorsed the idea of wilderness promoted by activists." Instead, "[c]ity officials [were] still anticipating an upper-income subdivision in the area" and its resulting property tax revenues (Herzberg 1988: 122). In fact, the Clear Lake Forest neighborhood on the banks of Armand Bayou was well under way in 1972. Thus, Pasadena's funding represents the first local government policy anomaly. Harris County, Houston and Pasadena lie within Harris County, provided the second needed to (re)produced Armand Bayou wilderness.

\section{The County Government policy anomaly}

Expressing growing concern for environmental protection, the loss of rural landscapes, and flooding, Harris County voters supported the creation of public parks in 1972. The voters passed a US\$5 million (US\$28 million in 2015) parks bond issue, the largest bond issue in the county at that point in time, to create a county-wide park system. Armand Bayou Nature Center became a focus for the new parks department due to strong citizen support. To acquire additional land for the nature center, the county also requested federal funds. The Bureau of Outdoor Recreation (BOR), under the U.S. Department of the Interior, provided funds to acquire and develop facilities for outdoor recreation. However, the State of Texas Parks and Wildlife Commission (TPWC) controlled the distribution of BOR funds and adamantly refused to make funds available to Armand Bayou on the grounds that Armand Bayou Nature Center would not provide traditional outdoor recreation such as hunting, fishing, and camping. Armand Bayou activists initiated a lobbying effort with Rogers Morton, Secretary of the Interior, former First Lady, Lady Bird Johnson, and U.S. Senator John Tower. This led BOR to refuse to release all federal allocated funds to the state of Texas. TPWC reversed its decision and agreed to fund Armand Bayou and, in response, the BOR reversed its decision and released funds including US $\$ 726,749$ for Armand Bayou. These federal funds were matched by US\$2 million (US\$11 million in 2015) in county funds. This allowed the county to purchase an additional 230 hectares (Washington Post Bureau 1972). The county government dissolved the county park system shortly after the final land purchase (Herzberg 1988: 126).

The complex land transactions that created ABNC resulted in land ownership by the City of Pasadena, Harris County, and a local foundation. To simplify governance, the county purchased the Pasadena's property at cost. Then, lacking a parks department to manage the land, the county worked with activists to incorporate a nonprofit organization, the Armand Bayou Nature Center (ABNC). The county retained ownership of the land and leased it to ABNC for 99 years (Anonymous 1976; Herzberg 1988). The overall funding sources for 
ABNC included the county, city of Pasadena, U.S. Federal Government, and private supporters. The total cost for ABNC's 650 hectares was over US\$5 million (\$28 million in 2015).

\section{Conclusion}

Today, the Armand Bayou Nature Center is among the largest urban wildlife refuges in the United States (Armand Bayou Nature Center 2009). According to the State of Texas Parks and Wildlife Department, Armand Bayou is one of the last bayous in Texas that is not channelized for flood control (Hegen 2010). Over 200 species of birds reside here or rely on the wetlands and forest as a safe resting place on migrations. The native prairies, brackish marshlands, and bottomland hardwoods are historically and ecologically important (Armand Bayou Nature Center 2016). ABNC is admired for its unspoiled beauty and variety of wildlife despite that fact that its neighbors include several major industrial chemical manufacturers, wastewater treatment plants, and extensive residential subdivisions. Materially and conceptually the ABNC is wilderness co-produced in and through suburbanization, industrialization, and extra-human processes. With its uneasy and often uncontrolled contradictions, wilderness is and always been integrated into our everyday landscapes. As a basic ingredient of American civilization, wilderness can be savage, a sublime call, or a paradox. Wilderness eludes human control as it deeply touches the human spirit. There is no need to search outside of ourselves for wilderness (Valadez 1987).

The key intersecting, and often internally contradictory, relations and processes in the (re)production of ABNC wilderness included the discovery of Texas oil, post-WWII suburbanization, the environmental movement, and the U.S. space program working at larger scales and interacting at the local and regional scale with wealthy oilmen, flooding, environmental activists, and urban developers. The discovery of Texas oil stimulated the development of the oil and refining industries on the Gulf Coast and financed the creation of the West Ranch. The West Ranch, a large parcel of land under single ownership, facilitated the Clear Lake City suburban and industrial development. The arrival of more people and their negative environmental impacts interacted with Middle/Armand Bayou. This suburban and industrial development stimulated calls for the protection of nature. Wilderness grew out of the perceived loss of nature. Increased flooding caused by subsidence and urban development stimulated calls to protect nature as a way to reduce flooding. Wilderness then grew out of human-exacerbated flooding. The nationwide environmental movement of the 1960s and 1970s manifest itself locally through federal funding for urban nature and activists such as Hana Ginzbarg and Terry Hershey. Local government and the development industry understood parks and nature preserves could increase urban development and thereby increase tax revenues and profits. Wilderness also grew out of the locally situated environmental movement.

The results presented here challenge us to envision ourselves and our societies in relation to wilderness and understand wilderness as co-produced in and through our efforts, and through extra-human processes and beings. The results suggest that approaching wilderness, conceptually and materially, less as 'thing' or 'entity' and more as a set of changing relations may be an avenue worthy of exploration. I argue that wilderness is and always has been integrated into our everyday suburban landscapes. Human and extrahuman practices and processes (re)produce wilderness in and through suburbanization and industrialization. As Willow (2015:173) has argued, "...solving our most urgent problems will require thinking about social and environmental issues not as separate entities, but as intricately related components of complex systems composed of human and non-humans alike." The results presented here support Willow's position but also suggest that we must do more than simply think differently. We must also act materially and physically within these complex systems, some of which remain beyond human control.

As an actor in the (re)production of wilderness, Exxon USA appropriately summarizes the immanent wilderness of terra economica. In 1977, Exxon, the Humble Oil and Refining Company's successor, published a beautifully illustrated, full-color second quarter report featuring ABNC, sub-titled Individuals and companies work to save a wilderness from metropolitan sprawl (Exxon USA 1977). A more accurate sub-title might have been, Individuals, companies, and extra-human others work to save and (re)create wilderness within metropolitan sprawl. 


\section{Bibliography}

Anonymous. 1970. Armand's Bayou: a statement by Frank Kokesh before the Harris County Commissioners Court on January 29,1970. Bayou Preservation Association, 1929-2003, Historical Collection (Series 11, Box 44, Folder 2), University of Houston Libraries, Houston, TX.

Anonymous. 1971. Bureau official urges park at Armand Bayou, Houston Chronicle October 31. Bayou Preservation Association, 1929-2003, Historical Collection (Series 11, Box 44, Folder 4), University of Houston Libraries, Houston, TX.

Anonymous. 1976. Center to develop Armand Park. Bayou Preservation Association, 1929-2003, Historical Collection (Series 11, Box 44, Folder 2), University of Houston Libraries, Houston, TX.

Anonymous. 2001. Historical vignette, Armand Yramategui, naturalist, educator, and conservationist. Along the Bayou: 2-3.

Armand Bayou Nature Center. 2016. About ABNC. [accessed January 28 2016]. http://www.abnc.org/aboutabnc/faqs.html.

Armand Bayou Nature Center. 2009. Armand Bayou Nature Center 2009 Annual Report. Houston, TX: The Armand Bayou Nature Center.

Bacon, A. 1995. The West Ranch: from cattle to space city. The Houston Review: History and Culture of the Gulf Coast XVII(2): 67-88.

Bryan, W.D. 2011. Poverty, industry, and enviromental quality: weighing paths to economic development at the dawn of the environmental era. Environmental History 16: 492-522.

Castree, N. 2000. Marxism and the production of nature. Capital \& Class 72: 5-36.

Castree, N. 2001. Socializing nature: theory, practice, and politics. In N. Castree and B. Braun (eds.) Social nature: theory, practice, and politics. Oxford: Blackwell Publishers Ltd.

City of Houston. 2011a. About Houston. [accessed November 8 2011]. http://www.houstontx.gov/abouthouston/houstonfacts.html

City of Houston. 2011b. Houston facts and figures. [accessed December 2 2011]. http://www.houstontx.gov/abouthouston/houstonfacts.html

Close-Up of America. 1978. A Texas city that's bustling out all over. U.S. News and World Report. November 27.

Cronon, W. 1995. The trouble with wilderness; or, getting back to the wrong nature. In W. Cronon (ed.) Uncommon ground: toward reinventing nature. New York: W.W. Norton.

Del E. Webb Corporation. 1962. General development plan: The West Ranch, Harris County, Texas. Phoenix, AZ: Del E. Webb Corporation.

DeLuca, K. and A. Demo. 2001. Imaging nature and erasing class and race: Carlton Watkins, John Muir, and the construction of wilderness. Environmental History 6(4): 541-560.

Desimini, J. 2014. From planned shrinkage to formerly urban: staking landscape architecture's claim in the shrinking city debate. Landscape Journal 33(1): 17-35.

Ekers, M., and A. Loftus. 2013. Revitalizing the production of nature thesis: a Gramscian turn? Progress in Human Geography 37(2): 234-252.

Exxon USA. 1977. Quarterly Report, 1977, Second Quarter. Bayou Preservation Association, 1929-2003, Historical Collection (Series 11, Box 47, Folder 3), University of Houston Libraries, Houston, TX.

Feagin, J.R. 1988. Free enterprise city. New Brunswick, NJ: Rutgers University Press.

Feagin, J.R. 1990. Are planners collective capitalists? The cases of Aberdeen and Houston. International Journal of Urban and Regional Research 14(2): 249-273.

Feldman, J. 2013. A storied wilderness: rewilding the Apostle Islands. Seattle, WA: University of Washington Press. 
Fisher, R. 2007. "Bad science": the politics of ozone air pollution in Houston. In M.V. Melosi and J.A. Pratt (eds.) Energy metropolis: an environmental history of Houston and the Gulf Coast. Pittsburgh, PA: University of Pittsburgh Press.

Gabrysch, R.K., and C.W. Bonnet. 1975. Land-surface subsidence in the Houston-Galveston Region, Texas. Austin, TX: Texas Water Development Board.

Gillaspy, M.J. 1970. Group aims to preserve the Bayou. Houston Chronicle, April 10. Bayou Preservation Association, 1929-2003, Historical Collection (Series 11, Box 44, Folder 2), University of Houston Libraries, Houston, TX.

Ginzbarg, H. 1971a. Letter from Hana Ginzbarg to Harold Scarlett, October 28. Bayou Preservation Association, 1929-2003, Historical Collection (Series 11, Box 44, Folder 4), University of Houston Libraries, Houston, TX.

Ginzbarg, H. 1971b. Letter from Hana Ginzbarg to Mayor Clyde Doyal, November 2. Bayou Preservation Association, 1929-2003, Historical Collection (Series 11, Box 44, Folder 4), University of Houston Libraries, Houston, TX.

Ginzbarg, H. 1971c. Letter from Hana Ginzbarg to Terry Hershey, November 7. Bayou Preservation Association, 1929-2003, Historical Collection (Series 11, Box 44, Folder 4), University of Houston Libraries, Houston, TX.

Ginzbarg, H. 1971d. Letter from Hana Ginzbarg to Friends of Armand Bayou. Bayou Preservation Association, 1929-2003, Historical Collection (Series 11, Box 48, Folder 8), University of Houston Libraries, Houston, TX.

Ginzbarg, H. 1972. Letter from Hana Ginzbarg to Miss Elsa Ransom, KPRC-TV, Houston, January 21. Bayou Preservation Association, 1929-2003, Historical Collection (Series 11, Box 44, Folder 3), University of Houston Libraries, Houston, TX.

Ginzbarg, H. 2005. How Armand Bayou Park and Nature Center came to be: setting the record straight. Interview by Tom Scarsella, in possession of the author.

Goldstein, J. 2013. Terra economica: waste and the production of enclosed nature. Antipode 45(2): 357-375.

Haase, D. 2008. Urban ecology of shrinking cities: an unrecognized opportunity? Nature and Culture 3(1): 18.

Harvey, D. 1996. Justice, nature and the geography of difference. Oxford: Blackwell.

Harvey, D. 2009. Cosmopolitanism and the geographies of freedom. New York: Columbia University Press.

Harvey, D. 2014. The seventeen contradictions and the end of capitalism. New York, NY: Oxford University Press.

Hegen, E. 2010. Protection of fragile coastal ecosystems: Texas Coastal Preserves. [accessed January 16 2016]. http://tpwd.texas.gov/fishboat/fish/didyouknow/coastpreserve.phtml.

Herzberg, J. 1988. Preserving Armand Bayou. The Houston Review: History and Culture of the Gulf Coast 10(3): 105-136.

Herzberg, J. 1995. Naturalist Armand Yramategui 1923-1970. The Houston Review: History and Culture of the Gulf Coast 17(1): 49-58.

Hester, R.T., N.J. Blazej, and I.S. Moore. 1999. Whose wild? Resolving cultural and biological diversity conflicts in urban wilderness. Landscape Journal 18(2): 137-146.

Hofmeister, S. 2009. Natures running wild: a social-ecological pespective on wilderness. Nature and Culture 4(3): 293-315.

Houston Audubon Society. 1970. The 'hoped-for' park on Armand Bayou. Bayou Preservation Association, 1929-2003, Historical Collection (Series 11, Box 44, Folder 2), University of Houston Libraries, Houston, TX.

Houston Galveston Subsidence District. 2011. Welcome to the Subsidence District. [accessed November 1 2011]. http://www.hgsubsidence.org.

Jacob, J. 2006. Armand Bayou Watershed Plan. College Station, TX: Texas Sea Grant. 
Jorgensen, A. (ed.). 2008. Urban wildscapes. Sheffield: University of Sheffield and Environmental Room Ltd.

Keil, R. and J. Graham. 1998. Reasserting nature: constructing urban environments after Fordism. In Braun, B. and N. Castree (eds.) Remaking reality: nature at the millenium. London: Routledge.

Kirby, A. and A.K. Lynch. 1987. A ghost in the growth machine: the aftermath of rapid population growth in Houston. Urban Studies 24: 587-596.

Kithiia, J. and A. Lyth. 2011. Urban wildscapes and green spaces in Mombasa and their potential contribution to climate change adaptation and mitigation. Environment and Urbanization 23(1): 251265. Researchgate

Langner, M., and W. Endlicher, eds. 2007. Shrinking cities: effects on urban ecology and challenges for urban development. Frankfurt am Main: Peter Lang.

Leopold, A. 1968 (1949). A Sand County almanac: sketches here and there. New York: Oxford University Press.

Lin, J. 1995. Ethnic places, postmodernism, and urban change in Houston. The Sociological Quarterly 36(4): 629-647.

Marsh, K.R. 2010. Drawing lines in the forest: creating wilderness areas in the Pacific Northwest: University of Washington Press.

Marx, K. 1923(1844). Economic and philosophical manuscripts of 1844. Moscow: Progress Publishers. [accessed January 21 2017].

McCarthy, J. 1998. Environmentalism, Wise Use and the nature of accumulation in the rural West. In Braun, B. and N. Castree (eds.) Remaking reality: nature at the millenium. London: Routledge. Pp. 126-149.

McFarlane, R.W. 1991. An environmental inventory of the Armand Bayou Coastal Preserve. Webster, TX: Galveston Bay National Estuary Program.

Melosi, M.V. 2007. Houston's public sinks: sanitary services from local concerns to regional challenges. In M.V. Melosi and J.A. Pratt (eds.) Energy metropolis: an environmental history of Houston and the Gulf Coast. Pittsburgh, PA: University of Pittsburgh Press.

Moore, J.W. 2011. Ecology, capital, and the nature of our times: accumulation and crisis in the capitalist world-ecology. Journal of World-Systems Research 17(1): 108-147.

Moore, J.W. 2014a. Beyond the 'exploitation of nature'? a world-ecological alternative. [accessed December 3 2015]. https://jasonwmoore.wordpress.com/2014/04/25/beyond-the-exploitation-of-nature-a-worldecological-alternative.

Moore, J.W. 2014b. The Capitalocene part 1: on the nature and origins of our ecological crisis. [accessed January 7 2016]. http://www.jasonwmoore.com/uploads/The_Capitalocene_Part_I June_2014.pdf

Moore, J.W. 2014c. The end of cheap nature: how I learned to stop worrying about 'the' environment and love the crisis capitalism. In Suter, C. and C. Chase-Dunn (eds.) Structures of the world political economy and the future of global conflict and cooperation. Berlin: LIT.

Muir, J. 1901. Our National Parks. Boston: Houghton Mifflin.

Nash, R. 1982. Wilderness and the American mind. 3rd ed. New Haven, CT: Yale University Press.

Nixon, R. 1971. Statement about the 'Legacy of Parks' program [accessed November 1 2011]. http://www.presidency.ucsb.edu/ws/?pid=3125

Olien, R.M. 2002. Oil in Texas: the gusher age, 1895-1945. Austin, TX: University of Texas Press.

Ollman, B. 2003. Dance of the dialectic: steps in Marx's method. Urbana: University of Illinois Press.

Oxford English Dictionary. 2011. immanent, adj., Second edition, 1989, online version September 2011. [accessed November 23 2011]. http://www.oed.com/view/Entry/91789

Pratt, J.A. 2007. A mixed blessing: energy, economic growth, and Houston's environment. In M.V. Melosi and J.A. Pratt (eds.) Energy metropolis: an environmental history of Houston and the Gulf Coast. Pittsburgh, PA: University of Pittsburgh Press. 
Reich, J. 2001. Re-creating the wilderness: shaping narratives and landscapes in Shenandoah National Park. Environmental History 6(1): 95-117.

Rink, D. 2009. Wilderness: the nature of urban shrinkage? The debate on urban restructuring and restoration in Eastern Germany. Nature and Culture 4(3): 275-292.

Scarlett, H. 1971. Bayou Park vs. suburb. Houston Post January 24. Bayou Preservation Association, 19292003, Historical Collection (Series 11, Box 44, Folder 3), University of Houston Libraries, Houston, TX.

Scarlett, H. 1972. Your world: a chance to help. Houston Post August 13. Bayou Preservation Association, 1929-2003, Historical Collection (Series 11, Box 44, Folder 2), University of Houston Libraries, Houston, TX.

Scarlett, H. 1973. Site of planned park viewed by naturalist. Houston Post, January 30. Bayou Preservation Association, 1929-2003, Historical Collection (Series 11, Box 45, Folder 3), University of Houston Libraries, Houston, TX.

Schmidt, D.H. 2008. The practices and process of neighborhood: the (re)production of Riverwest, Milwaukee, Wisconsin. Urban Geography 29(5): 473-495.

Shelley, M.W. 1999[1818]. Frankenstein, or, the modern prometheus: with connections. Austin: Holt, Rinehart and Winston.

Smith, J.F. 2014. The wilderness paradox. Orion September/October: 34-38.

Smith, N. 1990(1984). Uneven development: nature, capital and the production of space. Oxford, UK: Blackwell.

Smith, N. 1996. The production of nature. In G. Robertson (eds.) FutureNatural: nature, science, culture. London: Routledge. text

Sutter, P.S., and W. Cronon. 2009. Driven wild: how the fight against automobiles launched the modern wilderness movement: University of Washington Press.

Swyngedouw, E. 1996. The city as hybrid: on nature, society and cyborg urbanization. Capitalism Nature Socialism 7: 65-80. Researchgate

Swyngedouw, E. 1997. Power, nature and the city: the conquest of water and the poltical ecology of urbanization in Guayaquil, Ecuador: 1880-1930. Environment and Planning A 29(2): 311-332.

Texas Commission on Environmental Quality. 2014. Index of Superfund sites by county. [accessed January 27 2016]. https://www.tceq.texas.gov/remediation/superfund/sites/county/County

Thomas, D.O.B. 1994. Clear Lake City, 1963-1988: a planned community after twenty five years. Houston: University of Houston-Clear Lake.

Thoreau, H.D. 1914. Walking. Cambridge, MA: The Riverside Press.

Thoreau, H.D. 2009. The Maine woods. New Haven: Yale University Press.

U.S. Census Bureau. 1960. Summary population and housing characteristics. Washington, DC: The Bureau.

U.S. Census Bureau. 1970. Summary population and housing characteristics. Washington, DC: The Bureau.

U.S. Census Bureau. 1980. Summary population and housing characteristics. Washington, DC: The Bureau.

U.S. Census Bureau. 1993. 1990 census of population and housing. Washington, DC: The Bureau.

U.S. Fish and Wildlife Service. 2009. Species profile for Brown Pelican (Pelecanus occidentalis). [accessed September 29 2016]. http://ecos.fws.gov/ecp0/profile/speciesProfile?spcode=B02L

United States 88th Congress. 1964. An Act to establish a National Wilderness preservation system for the permanent good of the whole people, and for other purposes. Public Law 88-577 (16 U.S. C. 11311136), Second Session. Washington, DC.

Valadez, J.J. 1987. Review: Dreamtime: concerning the boundary between wilderness and civilization, by Hans Peter Duerr and Felicitas Goodman. Contemporary Sociology 16(3): 399-400.

Vojnovic, I. 2003. Laissez-faire governance and the archetype laissez-faire city in the USA: exploring Houston. Geografiska Annaler 85(1): 19-38. 
Vojnovic, I. 2007. Government and urban management in the 20th century: policies, contradications, and weaknesses of the New Right. GeoJournal 69: 271-300.

Washington Post Bureau. 1972. U.S. OKs Armand Bayou purchase aid in decision switch. Bayou Preservation Association, 1929-2003, Historical Collection (Series 11, Box 44, Folder 2), University of Houston Libraries, Houston, TX.

Williams, T.T. 2014. The glorious indifference of wilderness. Orion September/October: 50-54.

Willow, A.J. 2015. The shifting topology of enironmentalism: human-environment relationships and conceptual trends in two North American organizational histories. Nature and Culture 10(2): 157-177.

Zilkoski, D.B., L.W. Hall, G.J. Mitchell, V. Kammula, A. Singh, W.M. Chrismer, and R.J. Neighbors. 2001. The Harris-Galveston Coastal Subsidence District/National Geodetic Survey Automated Global Postioning System Subsidence Monitoring Project. Paper read at U.S. Geological Survey Subsidence Interest Group Conference, Proceedings of the Technical Meeting, November 27-29, at Galveston, Texas.

Ziser, M. 2011. Review of The wilderness paradox. Boom: A Journal of California 1(2): 88-91. 